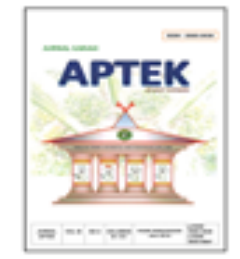

\title{
Menganalisis Pengaruh Ketidakberaturan Horizontal Torsi Terhadap Beban Gempa Pada Struktur Gedung Sistem Flat Slab-Drop Penel
}

\author{
Harriad Akbar Syarif ${ }^{\mathrm{a}, *}$, Zulfikar Djauhari ${ }^{\mathrm{b}}$, Ridwan ${ }^{\mathrm{c}}$
}

${ }^{a}$ Prodi Teknik Sipil, Universitas Pasir Pengarain, Jl. Tuanku Tambusai Kumu Rambah Hilir, Rokan Hulu.

b,c Jurusan Teknik Sipil, Universitas Riau, Kampus Bina Widya Jl. HR Soebrantas Km 12,5 Pekanbaru.

\section{N F O A R T I KE L}

Histori artikel:

Diajukan

Diterima dalam bentuk revisi

Diterima :

Tersedia Online :

\section{A B S T R A K}

Penelitian ini bentujuan menganalisis penganuh ketidakberaturan horizontal torsi. Struktur gedung berada di Kota Pekanbanu dengan fungsi sebagai hotel yang terdiri dari 19 lantai dengan ketinggian 62,1 m menggunakan material beton bertulang. Struktur gedung didesain dengan pembebanan gempa rencana yang menggunakan analis is respons spektum berdasarkan SNI 1726-2012. Pemodelan struktur gedung menggunakan tipikal denah struktur yang sama. Struktur dibagi menjadi dua model, yaitu Model A (dua lantai tingkat bawah menggunakan sistem flat slab-drop panel) dan Model B (keseluruhan lantai tingkat menggunakan sistem flat slab-drop panel). Hasil penelitian menunjukkan pada simpangan perpindahan, model A sebesar 1109,35 mm dan Model B sebesar menghasilkan simpangan perpindahan 1091,4 mm. Ketidakberaturan horizontal torsi ditinjau pada masingmasing lantai tingkat berdasarkan arah X dan Y. Ketidakberaturan torsi Model A pada arah X dan Arah Y dikategorikan memiliki ketidakberaturan torsi. Sedangkan ketidakberaturan torsi berlebih untuk arah X lantai tingkat 13, 14 dan pool deck tidak dikategorikan torsi berlebih, tetapi untuk arah Y semua lantai tingkat dikategorikan memiliki ketidakberaturan torsi berlebih. Sedangkan untuk Model B, ketidakberaturan torsi pada arah $\mathrm{X}$ dan Arah $\mathrm{Y}$ pada setiap lantai tingkat dikategorikan memiliki ketidakberaturan torsi. Ketidakberaturan torsi berlebih untuk arah X lantai tingkat 8 sampai dengan tingkat pool deck tidak dikategorikan torsi berlebih, akan tetapi lantai tingkat semibasement sampai dengan tingkat 7 dikategorikan memiliki ketidakberaturan torsi berlebih. Untuk arah Y semua lantai tingkat dikategorikan tidak memiliki ketidakberaturan torsi berlebih. Jika dibandingkan antara Model A dan B, Model B lebih dapat menahan momen torsi berlebih dibandingkan dengan Model A. Pengaruh momen torsi tersebut disebabkan adanya eksentris itas antara pusat mas sa bangunan dengan pusat rotasi bangunan.

Kata kunci: Beban Gempa; Ketidakberaturan Struktur; Sistem Flat Slab-Drop Panel ; Torsi

\section{E-M A I L}

harriadakbarsyarif@upp.ac.id* zulfikar.djauhari@lecturer.unri.ac.id ridwan@eng.unri.unri.ac.id

\section{A B S T RA C T}

This study aims to analyze the effect of horizontal torsion irregularity. The building structure is located in Pekanbaru City and functions as a hotel which consists of 19 floors with a height of $62.7 \mathrm{~m}$ using reinforced concrete material. The structure of the building is designed with an earthquake loading plan that uses response spectrum analysis based on SNI 1726-2012. Modeling of building structures using the same typical structural plan. The structure is divided into two models, namely Model $A$ (the lower two floors use a flat slab-drop panel system) and Model B (the whole level floor uses a flat slab-drop panel system). The results showed that at the displacement deviation, Model A was $1109.35 \mathrm{~mm}$ and Model B was $1091.4 \mathrm{~mm}$. Horizontal irregularity of torque is reviewed for each floor level based on $X$ and $Y$ directions. Torque irregularity Model $A$ in $X$ direction and $Y$ direction is categorized as having torque irregularity. Whereas excess torque irregularity for the $X$ direction of floors 13, 14 and pool deck is not categorized as excessive torque, but for $Y$ direction all level floors are categorized as having excess torque irregularity. Whereas for Model $B$, the torque irregularity in the $X$ direction and $Y$ direction on each floor level is categorized as having torque irregularity. Excess torque 
irregularity for the $X$ direction of floors 8 levels up to pool deck levels is not categorized as excessive torque, but semibasement floors up to level 7 are categorized as having excess torque irregularities. For the $Y$ direction all level floors are categorized as not having excess torque irregularity. When compared between Models $A$ and $B$, Model $B$ is more able to withstand excess torque moments than Model A. The effect of the torque moment is due to the eccentricity between the center of mass of the building and the center of rotation of the building.

Keyword: Earthquake Load; Structural Irregularity; Flat Slab-Drop Panel System; Torque

\section{PENDAHULUAN}

Setiap gedung terdiri dari elemen struktural (balok dan kolom) dan elemen non-struktural (partisi, plafond, pintu). Elemen struktural yang digabungkan akan menjadi satu sistem struktur yang kaku. Fungsinya adalah untuk mendukung berat sendiri, dan untuk menyalurkan gaya-gaya tersebut ke tanah, tanpa menganggu bentuk geometri, kesatuan, dan daya layan dari struktur secara signifikan [1].

Pelat adalah struktur planar kaku yang terbuat dari material monolit dengan tinggi yang kecil dibandingkan dengan dimensi-dimensi lainnya [2]. Untuk merencanakan pelat beton bertulang perlu mempertimbangkan faktor pembebanan dan ukuran serta syarat-syarat dari peraturan yang ada. Selain itu, Beban yang dipikul oleh pelat dapat berupa beban statik dan beban dinamik yang pada umumnya bekerja tegak lurus arah bidang pelat tersebut [3].

Struktur flat slab merupakan sistem struktur gedung dengan elemen utama berupa kolom dan pelat (tanpa balok). Kelebihan flat slab meliputi acuan perancah yang sederhana dan ekonomis, tinggi lantai yang lebih rendah sehingga mengurangi efek beban lateral dan pekerjaan mekanikal/ elektrikal [4]. Akan tetapi, timbul suatu masalah yang terdapat pada pertemuan kolom dan pelat. Pada titik pertemuan tersebut terjadi konsentrasi tegangan akibat gaya geser (punching shear). Untuk menghindari hal tersebut, dimensi ujung kolom diperbesar dengan penambahan penebalan (drop panel). Penebalan yang dilakukan untuk meminimalisir kegagalan yang terjadi pada sistem flat slab. Sehingga perencanaan drop panel menjadi perhatian khusus didalam meneruskan beban yang bekerja pada pelat.

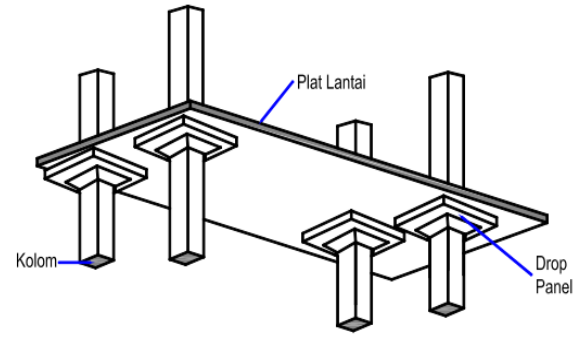

Gambar 1. Sistem Flat Slab Menggunakan Drop Panel

Respons struktur akibat gempa sangat dipengaruhi oleh bentuk bangunan itu sendiri. Bangunan dengan bentuk beraturan, sederhana, dan simetris akan berperilaku lebih baik terhadap gempa dibandingkan dengan bangunan yang tidak beraturan [5]. Sesuai dengan persyaratan pada Tabel 10 dan Tabel 11 pada SNI 1726-2012 Pasal 7.3.2, dilakukan pengecekan terhadap ketidakberaturan struktur horizontal dan ketidakberaturan struktur vertikal pada struktur bangunan. Masing-masing ketidakberaturan struktur yang terjadi memiliki pasal referensi masingmasing sebagai acuan untuk desain.

\section{MATERIAL DAN METODE}

Struktur gedung terletak di Kota Pekanbaru, dibangun pada tahun 2014 dan selesai pada tahun 2016 yang berfungsi sebagai hotel. Secara umum, bangunan ini dirancang dengan material beton bertulang dengan bentuk tidak beraturan dari segi horizontal maupun vertikalnya. Gedung ini mempunyai spesifikasi yang berbeda-beda untuk setiap bagian strukturnya terutama pada sistem flat slab.

Tabel 1. Data Umum Struktur

\begin{tabular}{ll}
\hline \multicolumn{1}{c}{ Kriteria } & \multicolumn{1}{c}{ Gedung } \\
\hline Sistem struktur & Dual System Wall-frame; \\
& Beton bertulang \\
Fungsi gedung & Hotel \\
Jumlah lantai & 19 lantai \\
Tinggi maksimum gedung & $62,7 \mathrm{~m}$ \\
\hline
\end{tabular}




\begin{tabular}{ll}
\hline Jumlah lantai basement & 2 \\
Luas total gedung & $28.050 \mathrm{~m}^{2}$ \\
Mutu Material & fc' Kolom, Dinding Geser = \\
Beton & 35 MPa ; Balok, Drop \\
& Panel, Pelat Lantai = 30 \\
& $\mathrm{MPa}$ \\
\hline Mutu Baja tulangan & $\mathrm{fy}=410 \mathrm{MPa}$ \\
\hline
\end{tabular}

Pemodelan struktur dilakukan menggunakan softwere elemen hingga dengan membuat dua pemodelan struktur. Model A merupakan struktur gedung yang memiliki dua lantai tingkat bawah (semibasement dan lantai tingkat dasar) yang menggunakan sistem flat slab-drop panel, sedangkan Model B merupakan stuktur gedung yang keseluruhan setiap lantai tingkatnya menggunakan sistem flat slabdrop panel. Berikut denah dan gambar 3D dari model struktur gedung yang ditinjau.

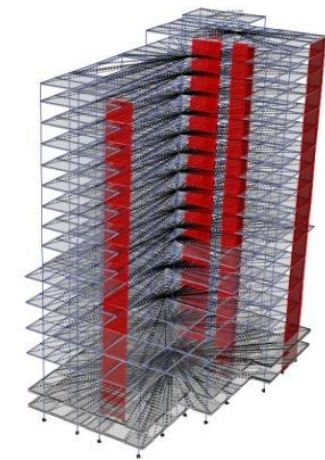

(a)

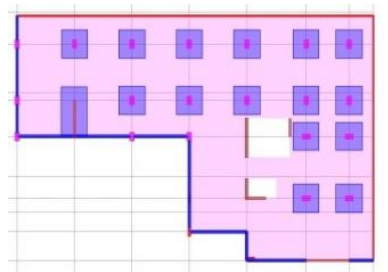

(b)
Gambar 2. Pemodelan Struktur pada Softwere Elemen Hingga

(a) Pemodelan Gedung 3D ; (b) Denah Tipikal Lantai

Struktur gedung beraturan, pengaruh gempa rencana dapat ditinjau sebagai pengaruh beban gempa statik ekuivalen, sehingga menurut standar ini analisisnya dapat dilakukan berdasarkan analisis statik ekuivalen. Struktur gedung yang tidak memenuhi ketentuan di atas, ditetapkan sebagai struktur gedung tidak beraturan. Untuk struktur gedung tidak beraturan, pengaruh gempa rencana harus ditinjau sebagai pengaruh pembebanan gempa dinamik, sehingga analisisnya harus dilakukan berdasarkan analisis respons spektrum[6].

Analisis struktur terhadap beban gempa mengacu pada Standar Perencanaan Ketahanan Gempa untuk Rumah dan Gedung (SNI 1726, 2012). Analisis struktur terhadap beban gempa pada gedung dilakukan dengan Metode Analisis Dinamik Respons
Spektrum. Level gempa menggunakan peta $2 \%$ kemungkinan gempa rencana terlampaui dalam 50 tahun umur bangunan. Dalam desain struktur bangunan ini, pembebanan gempa yamg digunakan untuk analisis adalah analisis respons spektrum sesuai data pengujian tanah pada lokasi struktur, yakni Pekanbaru. Parameter yang digunakan dalam analisis respons spektrum di peroleh berdasarkan data Peta Gempa Hazard 2017 sesuai koordinat lokasi yang diambil. Parameter - parameter yang digunakan dalam analisis respons spektrum dapat dilihat sebagai berikut.

1. Data Bangunan
a. Lokasi
: Kota Pekanbaru
b. Jenis bangunan
: Hotel
c. Jenis tanah
: Tanah Lunak
d. Jumlah tingkat
$: 19$
e. Tinggi bangunan
$: 68,5 \mathrm{~m}$

2. Faktor Reduksi (R) : 6

3. Faktor Keutamaan Bangunan (I) : 1,25

4. Percepatan Respons Spektral Periode Pendek, $\mathrm{S}_{\mathrm{s}}$

5. Percepatan Respons Spektral

Periode 1 detik, $\mathrm{S}_{1}$

6. Kategori Resiko

: Tipe III

Berdasarkan SNI 1726-2012, struktur bangunan gedung diklasifikasikan sebagai gedung beraturan dan tidak beraturan. Klasifikasi tersebut didasarkan pada konfigurasi horizontal dan vertikal dari struktur bangunan gedung. Secara khusus pada penelitian ini hanya membatasi masalah ketidakberaturan struktur dalam arah horizontal torsi seperti dapat dilihat pada Tabel 2 berikut.

Tabel 2. Ketidakberaturan Horizontal Struktur

\begin{tabular}{|c|c|c|c|}
\hline No & $\begin{array}{l}\text { Tipe Dan Penjelasan } \\
\text { Ketidakberaturan }\end{array}$ & $\begin{array}{c}\text { Pasal } \\
\text { Referensi }\end{array}$ & $\begin{array}{c}\text { Penerapan } \\
\text { Kategori } \\
\text { Desain } \\
\text { Seismik }\end{array}$ \\
\hline $1 \mathrm{a}$ & $\begin{array}{lr}\text { Ketidakberaturan torsi } \\
\text { didefinisikan ada jika } \\
\text { simpangan antar } \\
\text { lantai } \\
\text { maksimum, torsi yang } \\
\text { dihitung termasuk tak } \\
\text { terduga, di sebuah } \\
\text { ujung } \\
\text { melintang truktur } \\
\text { sumbu lebih dari } 1,2 \\
\text { kali simpangan antar } \\
\text { lantai tingkat rata-rata }\end{array}$ & $\begin{array}{c}7.3 .3 .4 \\
7.7 .3 \\
7.8 .4 .3 \\
7.12 .1 \\
\text { Tabel } 13 \\
12.2 .2\end{array}$ & $\begin{array}{c}\mathrm{D}, \mathrm{E} \text { dan F } \\
\mathrm{B}, \mathrm{C}, \mathrm{D}, \mathrm{E} \\
\text { dan F } \\
\mathrm{C}, \mathrm{D}, \mathrm{E} \\
\text { dan F } \\
\mathrm{C}, \mathrm{D}, \mathrm{E} \\
\text { dan F } \\
\mathrm{D}, \mathrm{E}, \text { dan F } \\
\mathrm{B}, \mathrm{C}, \mathrm{D}, \mathrm{E} \\
\text { dan F }\end{array}$ \\
\hline
\end{tabular}




\begin{tabular}{|c|c|c|c|}
\hline & $\begin{array}{lr}\text { di kedua } & \text { ujung } \\
\text { struktur. Persyaratan } & \text { Petidakberaturan torsi } \\
\text { ketidasal } \\
\text { dalam pasal-pasal } \\
\text { referensi } r \text { berlaku } \\
\text { hanya untuk } & \text { struktur } \\
\text { dimana diafragmanya } \\
\text { kaku atau setengah } \\
\text { kaku. }\end{array}$ & & \\
\hline $1 \mathrm{~b}$ & $\begin{array}{l}\text { Ketidakberaturan torsi } \\
\text { berlebihan } \\
\text { didefinisikan ada jika } \\
\text { simpangan antar } \\
\text { lantai } r \text { tingkat } \\
\text { maksimum, torsi yang } \\
\text { dihitung termasuk tak } \\
\text { terduga, di sebuah } \\
\text { ujung } \\
\text { melintang truktur } \\
\text { sumbu lebih dari } 1,4 \\
\text { kali simpangan antar } \\
\text { lantai tingkat rata-rata } \\
\text { dikedua } \\
\text { struktur. }\end{array}$ & $\begin{array}{c}7.3 .3 .1 \\
7.3 .3 .4 \\
7.7 .3 \\
7.8 .4 .3 \\
7.12 .1 \\
\text { Tabel } 13 \\
12.2 .2\end{array}$ & $\begin{array}{c}\text { E dan F } \\
\text { D } \\
\text { B, C dan D } \\
\text { C dan D } \\
\text { C dan D } \\
\text { D } \\
\text { B, C dan D }\end{array}$ \\
\hline
\end{tabular}

Dalam analisis struktur gedung terhadap beban gempa biasanya digunakan asumsi lantai yang sangat kaku tak terhingga sehingga distribusi beban yang diterima tiap kolom sebanding dengan kekakuan dan jarak terhadap pusat massa. Saat beban gempa bekerja lantai diafragma akan mengalami tegangan tarik, tekan dan geser sesuai kekakuan dan distribusi massa. Tegangan akan cukup berpengaruh jika terdapat kekakuan lateral kolom yang selisih besar dibanding lainnya seperti adanya dinding geser. [8]. Secara analisa diafragma dapat ditinjau sebagai elemen tegangan bidang (plane stress) dengan ditumpu oleh kekakuan tranversal kolom dan dinding geser, beban yang bekerja adalah distributed area loads untuk massa lantai, line loads untuk massa dinding dan concentrated load untuk massa terpusat [9].

Dalam analisis lantai diafragma, seharusnya kekakuan balok/drop panel diabaikan sehingga tegangan hanya diterima oleh pelat diafragma. Hal ini ditujukan untuk menjaga konsistensi perhitungan pada desain balok/drop panel itu sendiri karena hanya di desain menerima lentur/geser sumbu major serta torsi. Hasil analisis lantai diafragma dengan FEM yang terutama ditinjau adalah terhadap tegangan tarik, yang mana ini akan membutuhkan penulangan khusus tension chord diapraghm[10]. Sedangkan yang lainnya adalah tegangan tekan dan geser yang mana biasanya sudah memenuhi karena dimensi dari lebar diafragma yang besar.

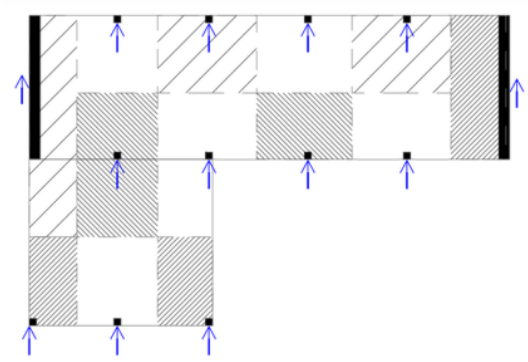

Gambar 3. Distribusi Beban Gempa pada Lantai dengan Asumsi Diafragma Fleksibel.

Diafragma merupakan pelat lantai yang menstabilkan dan menyalurkan gaya-gaya yang ditimbulkan oleh gempa antara sistem lantai dan sistem vertikal penahan gaya gempa, seperti kolom dan dinding struktural. Diafragma didesain sebagai bagian dari sistem penahan gaya gempa untuk setiap bangunan dengan Kategori Desain Seismik (KDS) B, C, D, E, hingga F berdasarkan SNI 1726-2012.

Berikut penjelasan mengenai pengecekan ketidakberaturan horizontal yang telah dilakukan.

1. Ketidakberaturan Torsi (Tipe 1a)

Ketidakberaturan torsi didefinisikan ada jika simpangan antar lantai tingkat maksimum, torsi yang dihitung termasuk tak terduga, di sebuah ujung struktur melintang terhadap sumbu lebih dari 1,2 kali simpangan antar lantai tingkat ratarata di kedua ujung struktur.

2. Ketidakberaturan Torsi berlebihan (Tipe 1b)

Ketidakberaturan torsi berlebihan didefinisikan ada jika simpangan antar lantai tingkat maksimum, torsi yang dihitung termasuk tak terduga, di sebuah ujung struktur melintang terhadap sumbu lebih dari 1,4 kali simpangan antar lantai tingkat rata-rata dikedua ujung struktur.

Persyaratan ketidakberaturan torsi menurut SNI 17262012 sebagai berikut.

1. $\delta_{\text {maks }} \times A_{x}<1,2 \delta_{\text {rata-rata, }}$ struktur tidak terdapat ketidakberaturan torsi.

2. $1,2 \delta_{\text {rata-rata }}<\delta_{\text {maks }} \times A_{x}<1,2 \delta_{\text {rata-rata }}$ struktur memiliki ketidakberaturan torsi.

3. $\delta_{\text {maks }} \times A_{x}>1,4 \delta_{\text {rata-rata }}$ struktur memiliki ketidakberaturan torsi berlebih. 


\section{HASIL DAN PEMBAHASAN}

Respons struktur akibat gempa sangat dipengaruhi oleh bentuk bangunan itu sendiri. Bangunan dengan bentuk beraturan, sederhana, dan simetris akan berperilaku lebih baik terhadap gempa dibandingkan dengan bangunan yang tidak beraturan [5]. Sesuai dengan persyaratan pada Tabel 10 dan Tabel 11 pada SNI 1726-2012 Pasal 7.3.2, dilakukan pengecekan terhadap ketidakberaturan struktur horizontal dan ketidakberaturan struktur vertikal pada struktur bangunan. Masing-masing ketidakberaturan struktur yang terjadi memiliki pasal referensi masingmasing sebagai acuan untuk desain.

Tabel 3. Ketidakberaturan Torsi Tipe 1a dan 1b Arah X Model A

\begin{tabular}{|c|c|c|c|c|c|c|}
\hline Lantai & $\begin{array}{c}\begin{array}{l}\text { Displa } \\
\text { cement }\end{array} \\
(\mathrm{mm})\end{array}$ & $\Delta \max$ & $\Delta$ avg & $\begin{array}{c}\Delta \max / \\
\Delta \text { avg } \\
(\mathrm{mm})\end{array}$ & $\begin{array}{c}\text { Status } \\
\text { Torsi } \\
\text { 1a }\end{array}$ & $\begin{array}{c}\text { Status } \\
\text { Torsi } \\
1 \mathrm{~b}\end{array}$ \\
\hline $\begin{array}{l}\text { POOL } \\
D E C K\end{array}$ & 2 & 996,9 & 726,7 & 1,372 & Ada & $\begin{array}{c}\text { Tidak } \\
\text { Ada }\end{array}$ \\
\hline LT. 14 & 67,5 & 978,4 & 707,7 & 1,383 & Ada & $\begin{array}{c}\text { Tidak } \\
\text { Ada }\end{array}$ \\
\hline LT. 13 & 55,8 & 940,8 & 676 & 1,392 & Ada & $\begin{array}{c}\text { Tidak } \\
\text { Ada }\end{array}$ \\
\hline LT. 12 & 51,6 & 895,3 & 639,4 & 1,400 & Ada & Ada \\
\hline LT. 11 & 51,3 & 843,7 & 598,9 & 1,409 & Ada & Ada \\
\hline LT. 10 & 36,7 & 787 & 555,2 & 1,418 & Ada & Ada \\
\hline LT. 9 & 49,9 & 725,8 & 508,8 & 1,426 & Ada & Ada \\
\hline LT. 8 & 68,6 & 661 & 461,2 & 1,433 & Ada & Ada \\
\hline LT. 7 & 72,6 & 592,8 & 412,9 & 1,436 & Ada & Ada \\
\hline LT. 6 & 111,8 & 521,9 & 362,1 & 1,441 & Ada & Ada \\
\hline LT. 5 & 123,2 & 460,4 & 314,1 & 1,466 & Ada & Ada \\
\hline LT. 4 & 122,5 & 350,7 & 237,5 & 1,477 & Ada & Ada \\
\hline LT. 3 & 112,7 & 241,2 & 162,3 & 1,486 & Ada & Ada \\
\hline LT. 2 & 10,4 & 140,4 & 93,6 & 1,500 & Ada & Ada \\
\hline $\begin{array}{l}\text { LT. } \\
\text { DASAR }\end{array}$ & 133 & 146,4 & 80,4 & 1,821 & Ada & Ada \\
\hline $\begin{array}{l}\text { SEMI } \\
\text { BASEM } \\
\text { ENT }\end{array}$ & 13,4 & 12,6 & 8,4 & 1,500 & Ada & Ada \\
\hline
\end{tabular}

Tabel 4. Ketidakberaturan Torsi Tipe 1a dan 1b Arah Y Model A

\begin{tabular}{lcccccc}
\hline Lantai & $\begin{array}{c}\text { Displa } \\
\text { cement }\end{array}$ & $\Delta \max$ & $\Delta$ avg & $\begin{array}{c}\Delta \text { max } \\
\Delta \text { avg }\end{array}$ & $\begin{array}{c}\text { Status } \\
\text { Torsi } \\
\text { 1a }\end{array}$ & $\begin{array}{c}\text { Status } \\
\text { Torsi } \\
1 b\end{array}$ \\
\cline { 2 - 6 } POOL & 35,4 & 852,2 & 577,8 & 1,475 & Ada & Ada \\
DECK & & & & & & \\
LT. 14 & 53,4 & 818,2 & 554,7 & 1,475 & Ada & Ada \\
LT. 13 & 58,2 & 767,4 & 521,5 & 1,472 & Ada & Ada \\
LT. 12 & 60,6 & 712,3 & 485,8 & 1,466 & Ada & Ada \\
LT. 11 & 62,5 & 655,3 & 448,7 & 1,460 & Ada & Ada \\
LT. 10 & 64,9 & 596,8 & 410,3 & 1,455 & Ada & Ada \\
\hline
\end{tabular}

\begin{tabular}{lcccccc}
\hline LT. 9 & 67,5 & 537 & 370,8 & 1,448 & Ada & Ada \\
LT. 8 & 70,1 & 476,2 & 330,1 & 1,443 & Ada & Ada \\
LT. 7 & 72,2 & 414,6 & 288,9 & 1,435 & Ada & Ada \\
LT. 6 & 61,4 & 353,2 & 247,4 & 1,428 & Ada & Ada \\
LT. 5 & 104,8 & 303 & 213,1 & 1,422 & Ada & Ada \\
LT. 4 & 101,2 & 220,7 & 156,5 & 1,410 & Ada & Ada \\
LT. 3 & 90,5 & 145 & 102,9 & 1,409 & Ada & Ada \\
LT. 2 & 81,7 & 81 & 57,2 & 1,416 & Ada & Ada \\
LT. & 28,4 & 79,2 & 43,1 & 1,838 & Ada & Ada \\
DASAR & & & & & & \\
SEMI & 11 & 6,7 & 4,7 & 1,426 & Ada & Ada \\
BASEME & & & & & & \\
NT & & & & & & \\
\hline
\end{tabular}

Menurut Tabel 3 dan 4, status torsi 1a adalah ketidakberaturan torsi sedangkan status torsi $1 \mathrm{~b}$ adalah ketidakberaturan torsi berlebih. Hasil yang didapat bahwasanya untuk Model A, ketidakberaturan torsi pada arah X dan Arah Y pada setiap lantai tingkat dikategorikan memiliki ketidakberaturan torsi. Sedangkan ketidakberaturan torsi berlebih untuk arah $\mathrm{X}$ lantai tingkat 13, 14 dan pool deck tidak dikategorikan torsi berlebih, tetapi untuk arah Y semua lantai tingkat dikategorikan memiliki ketidakberaturan torsi berlebih.

Pengaruh gaya gempa akan berbeda jika diaplikasikan terhadap bangunan beraturan dan tidak beraturan. Kinerja struktur yang dihasilkan untuk gedung tidak beraturan akan berbeda dengan gedung beraturan untuk intensitas beban yang sama, misalnya jika dibandingkan terhadap simpangan (displacement) dan simpangan antar lantai (drift) Dilihat dari denah tipikal lantai tingkat atas sepertiga struktur Model A, arah $\mathrm{X}$ memiliki panjang lebih besar dibandingkan arah $\mathrm{Y}$ sehingga kemungkinan besar terjadi torsi berlebih pada arah X.

Tabel 5. Ketidakberaturan Torsi Tipe 1a dan 1b Arah X Model B

\begin{tabular}{|c|c|c|c|c|c|c|}
\hline$\overline{\operatorname{Lan}}$ & $\begin{array}{c}\text { Displace } \\
\text { ment }\end{array}$ & $\Delta \max$ & avg & $\begin{array}{l}\Delta \max / \\
\Delta \text { avg } \\
\end{array}$ & $\begin{array}{l}\text { Status } \\
\text { Torsi }\end{array}$ & $\begin{array}{l}\text { Status } \\
\text { Torsi } \\
1 \mathrm{~b}\end{array}$ \\
\hline & (mm) & $(\mathrm{mr}$ & & (mm) & & \\
\hline $\begin{array}{l}P O O L \\
D E C K\end{array}$ & 304 & 1166 & & 8 & Ada & $\begin{array}{c}\text { Tidak } \\
\text { Ada }\end{array}$ \\
\hline$\Gamma 1$ &, 5 & $35-2$ & 847,2 & 1,341 & Ada & $\begin{array}{c}\text { Tidak } \\
\text { Ada }\end{array}$ \\
\hline LT. & 61,5 & 82 & 800,4 & 352 & Ada & $\begin{array}{c}\text { Tidak } \\
\text { Ada }\end{array}$ \\
\hline LT. 1 & 67,5 & 10007 & 7 & 362 & Ada & $\begin{array}{c}\text { Tidak } \\
\text { Ada }\end{array}$ \\
\hline LT. 11 & 72,6 & 953,2 & 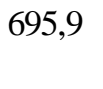 & ,370 & Ada & $\begin{array}{c}\text { Tidak } \\
\text { Ada }\end{array}$ \\
\hline LT. 10 & 76,5 & 880,6 & 0,9 & 1,374 & Ada & $\begin{array}{c}\text { Tidak } \\
\text { Ada }\end{array}$ \\
\hline LT. 9 & 79,4 & 804,1 & 81,6 & 1,383 & Ada & Tidak \\
\hline
\end{tabular}


Ada

\begin{tabular}{lcccccc} 
LT. 8 & 81,9 & 724,7 & 519,3 & 1,396 & Ada & $\begin{array}{c}\text { Tidak } \\
\text { Ada }\end{array}$ \\
LT. 7 & 84 & 642,8 & 456,3 & 1,409 & Ada & Ada \\
LT. 6 & 19,4 & 558,8 & 392,8 & 1,423 & Ada & Ada \\
LT. 5 & 141,1 & 487,4 & 339,9 & 1,434 & Ada & Ada \\
LT. 4 & 139,2 & 360,9 & 249,4 & 1,447 & Ada & Ada \\
LT. 3 & 122,1 & 234,3 & 161,8 & 1,448 & Ada & Ada \\
LT. 2 & 101,9 & 123,9 & 86,3 & 1,436 & Ada & Ada \\
LT. & 24,8 & 33 & 23,4 & 1,410 & Ada & Ada \\
$\begin{array}{l}\text { DASAR } \\
\text { SEMI }\end{array}$ & 10,3 & 9,7 & 6,8 & 1,426 & Ada & Ada \\
$\begin{array}{l}\text { BASEM } \\
\text { ENT }\end{array}$ & & & & & & \\
\hline
\end{tabular}

Tabel 6. Ketidakberaturan Torsi Tipe 1a dan 1b Arah Y Model B

\begin{tabular}{|c|c|c|c|c|c|c|}
\hline $\begin{array}{l}\text { POOL } \\
D E C K\end{array}$ & 43,2 & 899 & 643,5 & 1,397 & Ada & Tidak \\
\hline $\begin{array}{l}\text { DEC K } \\
\text { LT. } 14\end{array}$ & 64,2 & 858,9 & 614,5 & 1,398 & Ada & $\begin{array}{l}\text { Ada } \\
\text { Tidak } \\
\text { Ada }\end{array}$ \\
\hline LT. 13 & 69,3 & 799,7 & 573,7 & 1,394 & Ada & $\begin{array}{c}\text { Tidak } \\
\text { Ada }\end{array}$ \\
\hline LT. 12 & 71,1 & 736,1 & 530,2 & 1,388 & Ada & $\begin{array}{c}\text { Tidak } \\
\text { Ada }\end{array}$ \\
\hline LT. 11 & 72,2 & 671 & 485,5 & 1,382 & Ada & $\begin{array}{c}\text { Tidak } \\
\text { Ada }\end{array}$ \\
\hline LT. 10 & 73,3 & 605,2 & 439,9 & 1,376 & Ada & $\begin{array}{c}\text { Tidak } \\
\text { Ada }\end{array}$ \\
\hline LT. 9 & 74,7 & 539,1 & 393,6 & 1,370 & Ada & $\begin{array}{c}\text { Tidak } \\
\text { Ada }\end{array}$ \\
\hline LT. 8 & 76 & 472,9 & 346,9 & 1,363 & Ada & $\begin{array}{c}\text { Tidak } \\
\text { Ada }\end{array}$ \\
\hline LT. 7 & 77 & 407,1 & 300,2 & 1,356 & Ada & $\begin{array}{c}\text { Tidak } \\
\text { Ada }\end{array}$ \\
\hline LT. 6 & 64,6 & 342,5 & 253,8 & 1,349 & Ada & $\begin{array}{c}\text { Tidak } \\
\text { Ada }\end{array}$ \\
\hline LT. 5 & 107,7 & 290,6 & 216 & 1,345 & Ada & $\begin{array}{c}\text { Tidak } \\
\text { Ada }\end{array}$ \\
\hline LT. 4 & 102,1 & 207,5 & 154,8 & 1,340 & Ada & $\begin{array}{c}\text { Tidak } \\
\text { Ada }\end{array}$ \\
\hline LT. 3 & 88,8 & 132,9 & 99,1 & 1,341 & Ada & $\begin{array}{c}\text { Tidak } \\
\text { Ada }\end{array}$ \\
\hline LT. 2 & 74,9 & 71,4 & 52,7 & 1,355 & Ada & $\begin{array}{c}\text { Tidak } \\
\text { Ada }\end{array}$ \\
\hline $\begin{array}{l}\text { LT. } \\
\text { DASAR }\end{array}$ & 23 & 19,9 & 14,5 & 1,372 & Ada & $\begin{array}{c}\text { Tidak } \\
\text { Ada }\end{array}$ \\
\hline $\begin{array}{l}\text { SEMI } \\
\text { BASEM } \\
\text { ENT }\end{array}$ & 9,3 & 5,7 & 4,1 & 1,390 & Ada & $\begin{array}{c}\text { Tidak } \\
\text { Ada }\end{array}$ \\
\hline
\end{tabular}

Menurut Tabel 5 dan 6, status torsi 1a adalah ketidakberaturan torsi sedangkan status torsi $1 \mathrm{~b}$ adalah ketidakberaturan torsi berlebih. Hasil yang didapat bahwasanya untuk Model B, ketidakberaturan torsi pada arah X dan Arah Y pada setiap lantai tingkat dikategorikan memiliki ketidakberaturan torsi. Sedangkan ketidakberaturan torsi berlebih untuk arah $\mathrm{X}$ lantai tingkat 8 sampai dengan tingkat pool deck tidak dikategorikan torsi berlebih, akan tetapi lantai tingkat semibasement sampai dengan tingkat 7 dikategorikan memiliki ketidakberaturan torsi berlebih. Untuk arah Y semua lantai tingkat dikategorikan tidak memiliki ketidakberaturan torsi berlebih.

Struktur Model B merupakan struktur yang menggunakan sistem keseluruhan perkuatan flat-slab drop panel. Jika dibandingkan dengan Model A yang menggunakan sistem flat slab-drop panel (dua lantai tingkat) dan selebihnya menggunakan perkuatan sistem balok-kolom, Model B lebih dapat menahan momen torsi berlebih dibandingkan dengan Model A. Salah satu faktor yang harus diperhatikan dalam perencanaan bangunan tahan gempa adalah timbulnya momen torsi pada elemen bangunan. Pengaruh momen torsi tersebut disebabkan adanya eksentrisitas antara pusat massa bangunan dengan pusat rotasi bangunan[11]

\section{KESIMPULAN}

Berdasarkan analisis data dan pembahasan mengenai pengaruh ketidakberaturan horizontal torsi terhadap beban gempa pada struktur gedung sistem flat slab-drop panel, maka dapat diambil kesimpulan sebagai berikut :

1. Ketidakberaturan horizontal struktur Model A terdapat pada ketidakberaturan torsi (tipe 1a) dan ketidakberaturan torsi berlebih (tipe 1b) yang ditinjau dari arah X dan arah Y. Pada arah X, tipe 1a terjadi pada seluruh lantai tingkat sedangkan untuk tipe $1 \mathrm{~b}$ terjadi pada 3 lantai bagian atas pada struktur yaitu lantai tingkat 13, 14 dan pool deck. Pada arah Y, tipe 1a dan $1 \mathrm{~b}$ terjadi pada seluruh lantai tingkat struktur.

2. Ketidakberaturan horizontal struktur Model B (sistem flat slab-drop panel) terdapat pada ketidakberaturan torsi (tipe 1a) dan ketidakberaturan torsi berlebih (1b) yang ditinjau dari arah $\mathrm{X}$ dan arah Y. Untuk arah X, tipe 1a terjadi pada seluruh lantai sedangkan tipe $1 b$ terjadi pada setengah bagian lantai dari bawah, lantai tingkat semibasement - 7. Pada arah Y, tipe 1a terjadi pada seluruh lantai tingkat sedangkan tipe $1 \mathrm{~b}$ tidak ada satupun lantai tingkat terjadi ketidakberaturan 
3. Hasil keseluruhan analisis respons struktur yang dilakukan berupa nilai displacement, gaya geser dan tingkat kekakuan, Model B yang menggunakan sistem flat slab-drop panel memiliki respons yang baik terhadap gaya gempa yang bekerja.

\section{UCAPAN TERIMAKASIH}

Ucapan terimakasih kami sampaikan kepada pihak-pihak yang telah membantu dalam penelitian ini adalah :

1. Kedua orang tua penulis, Bapak Ahmad Syarif, SE dan Ibu Dra. Nuraini serta adik Muqti Randy Syarif, SE.

2. Bapak Dr. Zulfikar Djauhari, MT dan Bapak Dr. Ridwan, MT selaku pembimbing dalam melakukan penelitian.

3. Seluruh Bapak dan Ibu civitas akademika Fakultas Teknik Universitas Pasir Pengaraian.

\section{DAFTAR PUSTAKA}

[1] B. Budiono and E. B. Wicaksono, "Perilaku Struktur Bangunan dengan Ketidakberaturan Vertikal Tingkat Lunak Berlebihan dan Massa Terhadap Beban Gempa," J. Teor. dan Terap. Bid. Rekayasa Siil, vol. 23, no. 2, pp. 113-126, 2016.

[2] J. Russell, "Progressive Collapse of Reinforced Concrete Flat Slab structures .," 2015.

[3] M. R. Islam, A. Ali, and M. E. Tahir, "Study on the Concentration of Moment at Slabcolumn Joints Due to Presence of Shear Walls in Different Positions," J. Civil, Constr. Environ. Eng., vol. 2, no. 5, pp. 140-146, 2017.

[4] G. G. Wang, "Performance of Reinforced Concrete Flat Slabs Exposed to Fire," 2016.

[5] M. Tarigan et al., "Perbandingan Respon Struktur Beraturan dan Ketidakberaturan Horizontal Sudut Dalam Akibat Gempa Dengan Menggunakan Analisis Statik Ekivalen dan Time History," J. Tek. Sipil Univ. Sumatra Utara, 2015.

[6] P. Risdanareni, Tavio, and A. Subekti, "Analisis Pengaruh Variasi Hubungan Tegangan Regangan Beton dan Bentang Bangunan Terhadap Kinerja Struktur Rangka Tiga Dimensi dengan Metode Nonlinear Statik Pushover," J. Insitut Teknol. Bandung, pp. 6167, 2017.

[7] SNI 1726, "Tata Cara Perencanaan Ketahanan Gempa Untuk Struktur Bangunan Gedung dan Non Gedung," Badan Standar Nas. Indones., 2012.

[8] R. Suryanita, H. Maizir, and H. Jingga, "Prediction of Structural Response due to
Earthquake Load using Artificial Neural Networks," Int. Conf. "Engineering Technol. Comput. Basic Appl. Sci., 2016.

[9] B. Budiono and M. Kristalya, Desain dan Evaluasi Gedung 38 Lantai Beton Bertulang Tahan Gempa dengan Sistem Ganda Rangka Pemikul Momen Khusus dan Dinding Struktural Khusus. 2017.

[10] R. Suryanita, H. Maizir, and H. Jingga, "Prediction of Structural Response Based on Ground Acceleration using Artificial Neural," Int. J. Technol. Eng. Stud., vol. 3, no. 2, pp. 74-83, 2017.

[11] D. D. Joshi and P. B. Murnal, "Performance of Flat Slab Structure Using Pushover Analysis," J. Mech. Civ. Eng., vol. 8, no. 3, pp. 41-44, 2013. 